\title{
A Classification of Different Approaches to Green Finance and Green Monetary Policy
}

\author{
Ewa Dziwok ${ }^{1, *(\mathbb{D})}$ and Johannes Jäger ${ }^{2}(\mathbb{D}$ \\ 1 Department of Applied Mathematics, University of Economics in Katowice, 40-287 Katowice, Poland \\ 2 Study Program Banking and Finance, University of Applied Sciences BFI Vienna, 1020 Vienna, Austria; \\ johannes.jaeger@fh-vie.ac.at \\ * Correspondence: ewa.dziwok@ue.katowice.pl
}

Citation: Dziwok, E.; Jäger, J. A Classification of Different

Approaches to Green Finance and Green Monetary Policy. Sustainability 2021, 13, 11902. https://doi.org/ $10.3390 /$ su132111902

Academic Editors: Agnieszka Bem, Paulina Ucieklak-Jeż, Paweł Prędkiewicz and Rafał Siedlecki

Received: 30 September 2021

Accepted: 25 October 2021

Published: 28 October 2021

Publisher's Note: MDPI stays neutral with regard to jurisdictional claims in published maps and institutional affiliations.

Copyright: (C) 2021 by the authors. Licensee MDPI, Basel, Switzerland. This article is an open access article distributed under the terms and conditions of the Creative Commons Attribution (CC BY) license (https:// creativecommons.org/licenses/by/ $4.0 /)$.
Abstract: In recent years, green finance has emerged as a commonly used strategy for dealing with environmental problems. However, it still remains to be seen whether green finance deals effectively with current global environmental problems. More recently, proposals regarding greening monetary policy have emerged. The goal of this paper is to provide a conceptual framework that helps to distinguish between different forms of green finance and monetary policy. We systematically analyse forms, tools and measures of green finance and monetary policy against different theoretical backgrounds. In so doing, we fill a research gap by providing an appropriate classification that is intended to facilitate future academic research. We provide different categories and distinguish, on an abstract level, between neoliberal, reformist and progressive forms of green finance. Furthermore, we provide sub-categories on a more concrete level of abstraction. With this, we focus on both financial market regulation and monetary policy strategies. Against the background of our categorisation, the different focuses on green finance and green monetary policy and the (often implicitly) underlying theoretical assumptions become transparent. The classification has significant implications for the evaluation of different perspectives and is, therefore, important for academic debate. The classification also potentially represents a basis for policy related discussions. We conclude that neoliberal forms of green finance and monetary policy that rely on the assumption of the effectiveness of markets for contributing to sustainability tend to neglect or abstract from potentially adverse distributional effects. Reformist forms of green finance and monetary policy are more skeptical of the effectiveness of market processes and, therefore, consider a greater role for government policies. In addition, reformist approaches are more concerned about the potentially adverse distributional effects of environmental policies. Finally, progressive green finance and monetary policy adopts a more global perspective on environmental issues and links the discussion intrinsically with questions of global inequality and socio-ecological transformation. Moreover, progressive approaches are skeptical of global capitalism at a systemic level and therefore demand global rules and financial and monetary regimes that allow for solutions of environmental problems based on global solidarity and a democratic economic governance.

Keywords: green finance; green monetary policy; sustainable finance; sustainable monetary policy; classification; conceptual framework; sustainability; socio-ecological transformation

\section{Introduction}

Against the background of environmental problems such as climate change and loss of biodiversity, green finance has become an important strategy for the financial sector and an important point of reference for government policies. Green finance emerged out of the ashes of the global financial crisis of 2008 and has its origin in private financial sector strategies. It represents the financial industries' first concerted approach as Berrou et al. [1] (p. 4) argue: 
"[G]reen finance represents the global financial community's first structured attempt to join financial performance and positive environmental impact $[\ldots]$ ]"

The financial industry and its partners as well as trans-national corporate leaders are prominent actors in the public discussion on green finance. This is for good reason. Green finance offers new profit opportunities for the financial industry [2]. More recently, public policy initiatives in the field of financial market regulation, public finances and monetary policy have also become more prominent. For example, the European Parliament, together with the European Commission [3] and the EU Technical Expert Group (TEG) [4], have presented a taxonomy that is expected to provide a framework for green finance to work more effectively. A strategy for financing the transition to a sustainable economy was issued by the European Commission [5]. Moreover, a discussion at the level of central banks (e.g., European Central Bank's climate action plan [6], the People's Bank of China's Guidelines for Establishing Green Finance [7]) has emerged with the aim of proposing strategies for dealing with climate change and the role of finance and monetary policy therein. There are also initiatives at the international level such as UNCTAD's Global Green New Deal proposal [8] and numerous national initiatives to boost green finance. Moreover, in the field of development finance, there is a significant trend toward green finance [9].

Hence, the question arises as to the extent to which these diverse initiatives and activities, under the banner of green finance and monetary policy, contribute to dealing with environmental challenges. The problem is that currently no general theoretical framework or classification exists that allows the discussion of these numerous and diverse approaches and strategies in green finance and green monetary policy in a systematic way. This absence of a classification makes a structured discussion about different general approaches in green finance and green monetary policy and their possible effects very difficult. In order to fill this gap and to allow systematically analyzing the potential of the diverse existing strategies, the paper provides a classification of different forms of green finance and green monetary policy. Hence, our analytical categorization and the joint analysis of financial market regulation and monetary policy strategies for greening the economy are intended to facilitate the academic debate about different approaches and provide a systematic basis for policy discussions and decisions.

\section{Methodology}

The methodology for our conceptual contribution is based on deductive theoretical reasoning. In so doing, we provide a classification that distinguishes different forms of green finance and monetary policy. Our classification relates the tools and intended mechanisms of action to the (implicitly) underlying general theoretical perspectives or paradigms, namely, neoclassical economic approaches, heterodox economic and environmental perspectives and critical political economy approaches. The use of this broad range of central essential theoretical perspectives is intended to avoid a one-sided and too narrow analysis of green finance and green monetary policy but to provide a broad scientific basis for classification instead. While our classification is inspired by Jäger and Schmidt [10], it substantially goes beyond their method by providing a more detailed and more systematic perspective and analysis. In addition, we do not analyze the discussion of green financial policies and green monetary policies in a separated way but rather show the interconnectedness of both policy fields in terms of the common assumptions and perspectives they share. This systematic classification is an important contribution of our paper. Based on the different theoretical foundations, we distinguish between neoliberal, reformist and progressive forms of green finance and monetary policy and additionally suggest sub-categories within the three main categories. The sub-categories are derived from more specific categories at lower levels of abstraction within the broader general theoretical perspectives. In order to illustrate our categorization, we provide examples of recent policy initiatives and proposals when considered necessary. Methodologically, we relied on relevant literature for private approaches to green finance, and in addition, we screened publications and webpages of important international and national public 
institutions and central banks in order to consider the most recent measures and proposals. We do not provide an extensive literature review nor a systematic review of all the initiatives and proposals but selected examples for illustrating purposes in order to make our conceptualization and its implications more accessible to the reader. Finally, we do not just analyze the different approaches but also assess them critically from different theoretical perspectives in order to facilitate further discussion about the possible mechanisms and effectiveness of different forms of green finance and green monetary policy.

\section{A Classification of Green Finance and Monetary Policy}

Different institutions provide different definitions of green finance. However, in general, the term refers to financial stocks and flows that aim to achieve environmentrelated sustainable development goals [1]. Green finance is part of the broader concept of sustainable finance, a term that explicitly includes social issues, while climate finance is a narrower element of green finance [11]. We prefer to use the terms green finance and green monetary policy in this contribution, even when we do consider social issues in our classification.

Many measures discussed today build on the assumption that market forces and individual corporate strategies in green finance and monetary policy are viable and effective in promoting sustainability. This is why such approaches can be classified as neoliberal. However, while these measures can be justified against the background of neoclassical economics, there are important differences regarding the role of the state in green finance and monetary policy. In current political discussion and proposals, we also find approaches that go beyond this neoliberal perspective. They are much more skeptical about the potential of markets to deal with environmental issues and see, therefore, a much stronger role of the state in providing the framework for green finance. In order to effectively achieve environmental goals and incorporate the dimension of social sustainability, these approaches underline the need for public finance and explicit monetary policy strategies. Such tools and policies stand in the tradition of the broader perspective of heterodox approaches to ecological economics $[12,13]$. We categorize these approaches as reformist green finance as they assume an important role for the state and go beyond a liberal perspective on market regulation and environmental problems. Moreover, reformist green finance and green monetary policy includes the social dimension of sustainability in terms of distributional issues. Notwithstanding this, reformist green finance assumes that a reformed capitalist economic system and green capitalism will have the capacity to effectively deal with today's global environmental challenges. Finally, there is an approach that is more skeptical of the capacity of capitalist market economies to deal with environmental problems. Such an approach relies on the theoretical background of critical political economy perspectives $[14,15]$ and holds that a more fundamental socioecological transformation of the global economic system should be undertaken $[13,16]$. We characterize financial and monetary policy strategies that aim at and support such a tradition as progressive.

\subsection{Neoliberal Forms of Green Finance and Green Monetary Policy}

The term neoliberal is used to refer to a set of policies that rely primarily on market forces, tend to restrict the public sector's active engagement and promote the private sector. Neoliberal policies often go together with distributional implications in favor of capital and the wealthy and may also rely on authoritarian state intervention [17,18]. Neoliberal forms of green finance and monetary policy strategies can be justified by mainstream neoclassical economics, in particular, environmental economics [19]. We distinguish three different types of neoliberal green finance in the area of financial markets and monetary policy (see Table 1). 
Table 1. Neoliberal forms of green finance and monetary policy.

\begin{tabular}{|c|c|c|}
\hline Types & Elements and Tools of Green Finance & Monetary Policy Tools and Strategies \\
\hline $\begin{array}{l}\text { Laissez-faire neoliberal green } \\
\text { finance and monetary policy }\end{array}$ & $\begin{array}{l}\text { financial investor (corporate) behavior } \\
\text { (CSR, ESG) and private finance deal } \\
\text { with environmental issues } \\
\text { green financial assets and services } \\
\text { contribute to profitability } \\
\text { no coherent climate policy-freely } \\
\text { determined climate risk measures } \\
\text { and markets; lack of } \\
\text { environmental regulations } \\
\text { limited public financial spending on } \\
\text { green investments }\end{array}$ & $\begin{array}{l}\text { - } \quad \text { price stability at the top of the monetary } \\
\text { goals pyramid } \\
\text { traditional monetary policy strategy } \\
\text { focusing on inflation targeting } \\
\text { - } \quad \text { key role of interest rates in monetary } \\
\text { transmission mechanism to } \\
\text { control inflation } \\
\text { - } \quad \text { traditional Quantitative Easing } \\
\text { (QE) practices }\end{array}$ \\
\hline
\end{tabular}

- $\quad$ environmental problems are caused by externalities and should be internalized

- (indirectly) subsidizing private sector through tax reduction or tax credits for environment friendly production

Standard neoliberal green finance and monetary policy

- $\quad$ support private green investment via green subsidies, guarantees, socialization of private debt, etc.
- $\quad$ traditional monetary policy instruments enhanced by green $\mathrm{QE}$ and targeted longer-term green refinancing operations

- reduction of minimal capital requirements for green lending

- $\quad$ proposals of a Central Bank Digital Currency (CBDC) that can be used to target specific private green investment

- implementation of regulations supporting the development of private green finance

- market-making, transparent, non-binding standards and measures of climate risk assessment and management Market-making neoliberal green
finance and monetary policy
- $\quad$ obligatory inclusion of climate risk and climate-related risks into overall risk assessment in the financial sector

- integrating sustainability factors into central bank portfolio management to green the balance sheet

\section{official taxonomies defining green} activities and environmental risks

\subsubsection{Laissez-Faire Neoliberal Green Finance and Green Monetary Policy}

Laissez-faire neoliberal green finance expects that individual behavior of corporations, e.g., in the areas of corporate social responsibility (CSR) and/or financial investment strategies following ESG (environmental, social and governance) criteria, are effective in managing environmental problems. This is very much in line with the idea that financial investors' behaviors are a central element in dealing with environmental problems as promoted by private investors such as Larry Fink, CEO of BlackRock [20], as well as by banking supervisory institutions such as the European Banking Authority (EBA) [21].

This optimistic perspective regarding the potential of private (financial) agents can be criticized within the neoliberal perspective itself [22]. The assumption that voluntary "green" investment behavior makes a difference is largely at odds with the efficient market hypothesis [23], the dominant perspective regarding the functioning of financial markets today. This perspective suggests that the prices of financial assets are not determined by the demand for them but by rational expectations regarding the future returns. The perspective holds that if some (or even many) market participants are irrational (or prefer green investment), the prices of financial assets, and hence, the investment conditions for different industries, will still be determined by the expected returns (and not by the demand for these assets). Individual strategies of investing in green bonds, shares or other financial instruments due to rebalancing effects are expected to have at best a minor impact on prices, financing conditions and the real economy [24]. In a less optimistic view, short- or medium-term deviations of equilibrium prices and market distortions may occur but only as a temporary phenomenon. Hence, while individual behavior 
in the form of green consumption changes the form of production and the structure of output, and therefore, undoubtedly has a positive environmental impact. This is far less the case of private green investment within the context of efficient financial markets. Therefore, it is not surprising that it is so difficult to find empirical evidence showing any significant effectiveness of private green investor behavior [9]. Based on a recent review of empirical literature [25], investor impact is at best very modest and can be found most often when financial markets are not efficient and small or less-established firms face financing constraints. Notwithstanding this, it is often argued that such voluntary approaches by investors may help to solve global environmental problems. However, Weber and ElAlfy [2] (p. 73) conclude that the promotion of green finance by financial industry takes place " $[\ldots]$ only as far as it has direct positive impact on the business or as long as it has positive impact on the reputation". This goes along with widely critiqued "greenwashing" in the financial sector [26], whereby companies offering green products continue to promote traditional "brown" products and "brown" investment is, consequently, not significantly constrained.

The promotion of green finance by the financial industry is a product differentiation tactic that helps to attract new groups of private investors as clients and allows the industry to offer "new and improved" forms of profitable financial services. However, it may be doubted even against a background of neoclassical environmental economics that relying exclusively or mainly on these private strategies will effectively help solve global environmental problems.

In the field of monetary policy, a radical neoliberal approach implies a continuity of traditional monetary policy following the consensus model [27]. This implies a focus on inflation targeting and the use of so-called non-discriminatory instruments (e.g., open market policies, interest rate policy and "traditional" Quantitative Easing $(\mathrm{QE}))$. It is based on the assumption that a sound monetary environment (price stability) and financial market stability are essential for markets to work effectively. Monetary policy should not intervene at a microeconomic level, i.e., it should not deal with environmental issues what are considered microeconomic phenomena.

This standard approach to monetary policy has been criticized, not just because of adverse distributional effects of QE [28] but also because it does not discriminate between "green" and "brown" activities and, therefore, contributes to environmental degradation [29]. This radical laissez-faire approach regarding environmental issues has been put, at least in part, into question by central banks, e.g., the European Central Bank (ECB) [6].

\subsubsection{Standard Neoliberal Green Finance and Green Monetary Policy}

This perspective encompasses a less radical and more conventional neoclassical view that builds on the assumption that environmental problems are caused by externalities that can be internalized by either taxes and/or subsidies [30]. While taxes and/or increasing the costs for capital are considered reformist approaches, subsidies to companies and the financial sector are classified as standard neoliberal green finance because of the different distributional implications. In the context of green finance, this approach is reflected by promoting the (indirect) subsidization of private green investment as an effective policy approach [31,32]. These subsidies can take the form of public guarantees such as de-risking Private-Public Partnerships (PPPs) [33] or green credit guarantee schemes (GCGSs) [34]. It is criticized that these measures use public money to increase profitability for private investors as has been the case in Africa [35]. Directly supporting private investors tends to imply adverse effects on the distribution of income and wealth. This is why such an approach can be classified as standard neoliberal green finance.

In the area of monetary policy, a standard neoliberal approach supports using measures that improve financing conditions for private green investment. Such a strategy builds on traditional monetary policy measures and combines them with innovative instruments such as targeted longer-term green refinancing operations, green $\mathrm{QE}$, a reduction in the minimal capital requirements for green lending, etc. [36-38]. 
In addition, proposals of a central bank digital currency (CBDC) that can be used to target specific private green investment can be seen as an innovative approach. This has not yet been subject to profound academic debate, but it has been discussed in the broader public [39]. These measures by central banks do indeed reduce financing costs, thereby subsidizing green activities. In so doing, they contribute to increasing investment in the targeted areas.

However, supporters of the consensus model criticize such an approach as, according to them, monetary policy should not interfere with microeconomic policy goals such as environmental issues [40]. Moreover, central banks have tended to be keen on maintaining market neutrality [41]. However, critical political economists and heterodox approaches argue that market neutrality is a myth, and that monetary policy has necessarily asymmetric implications and potentially important distributional effects [42,43].

\subsubsection{Market-Making Neoliberal Green Finance and Green Monetary Policy}

Policies and regulations that create and support markets can be subsumed under the banner of market-making neoliberal green finance. Such policies do not just include regulations regarding property rights but also standards such as "green" taxonomies. Standardization measures are expected to increase transparency and facilitate the creation and functioning of markets and financial instruments [44]. This is expected to make markets work more effectively for environmental goals [45].

The EU taxonomy [3] is an important and well-developed example defining standardized criteria for classifying and rating green investments, allowing, for example, for the comparison of different (green) mutual funds. In developing the taxonomy, the EU relied heavily on input from private finance. The taxonomy is expected to provide a level playing field for the banking industry and improve its reputation in the context of accusations of greenwashing. In so doing, it should enhance business opportunities by increasing the demand for green financial products.

However, it is criticized that a standardization and increasing transparency do not offset the problems that go with commodification of nature. Markets based on private property rights assume commensurability of different environmental goods and physical capital and nature. According to this critical perspective, the privatization of nature often implies dispossession. Therefore, the creation of (financial) markets for environmental goods does not contribute effectively to solving environmental problems and has potentially adverse distributional implications [46,47].

Market-making in the area of monetary policy includes the obligatory inclusion of climate risk and climate-related risks into overall risk assessment in the financial sector, including financial stability monitoring and prudential regulation [48]. This goes along with the requirements for the disclosure of environmental risks and the requirements for banks to consider environmental risks before lending. Such monetary policy measures rely heavily on taxonomies that define green activities and environmental risks [49,50] and can, therefore, be considered to be a central element of a market-making neoliberal monetary policy. The recent proposal by the ECB [6] is an important example of such a set of market-making policies.

It is critiqued that these monetary policies are one-sided. While taking environmental risks into account is appreciated, these policies' support of green investment and green activities should have explicit "penalties" for "brown" activities [51].

\subsection{Reformist Forms of Green Finance and Green Monetary Policy}

The term reformist refers to approaches that deviate from a neoliberal perspective in that they are more skeptical of markets and see a more active role for the state in achieving environmental goals. Moreover, distributional effects of green finance and green monetary policies are considered important. Such reformist forms of green finance tend to put the costs onto private corporates and the financial sector while supporting less-wealthy households. Hence, contrary to standard neoliberal approaches, reformist green finance 
does not subsidize environmentally preferable activities but taxes those activities that are environmentally problematic (nevertheless compensating households where these taxes have problematic distributional effects) and uses financial resources for public environmental policies such as the provision of green infrastructure. Moreover, within this reformist perspective, green finance is considered based on strict environmental rules rather than on the profit motive of investors. On a theoretical level, reformist approaches to green finance can be supported in part by neoclassical environmental economics but mainly by heterodox approaches to environmental issues [13,52]. A reformist approach restricts private capital flows and promotes the public provision of environmental goods (instead of private green finance and private sector investment). In the field of monetary policy, it encourages and supports public environmental investment strategies by central banks [8]. Reformist green finance, hence, relies on two important pillars that are complementary: taxes and public finance, what we categorize as tax-based reformist public green finance, and command and control policies within the field of green finance, both in particular and in the economy in general (see Table 2).

Table 2. Reformist forms of green finance and monetary policy.

\begin{tabular}{|c|c|c|}
\hline Types & Elements and Tools of Green Finance & Monetary Policy Tools and Strategies \\
\hline $\begin{array}{l}\text { Tax-based reformist public green } \\
\text { finance and monetary policy }\end{array}$ & $\begin{array}{l}\text { taxes on environmentally problematic } \\
\text { activities (carbon tax) but avoiding } \\
\text { adverse distributional implications } \\
\text { green public finance based on revenues } \\
\text { from taxing higher income and wealth } \\
\text { green public investment and spending } \\
\text { on environmental issues }\end{array}$ & $\begin{array}{l}\text { - } \quad \text { monetary policy directly } \\
\text { supports green public activities } \\
\text { and investments } \\
\text { central bank provides necessary } \\
\text { sources to transform the economy } \\
\text { towards sustainability } \\
\text { monetary policy supports public } \\
\text { development banks }\end{array}$ \\
\hline $\begin{array}{l}\text { Command and control policies in } \\
\text { green finance and monetary policy }\end{array}$ & $\begin{array}{l}\text { - } \quad \text { gommand and control policies that } \\
\text { rules that support public environmental } \\
\text { investment and spending } \\
\text { binding regulations for the financial } \\
\text { sector that forbid or enforce specific } \\
\text { economic activities }\end{array}$ & $\begin{array}{l}\text { monetary policy provides strict rules } \\
\text { that encourage private banks to } \\
\text { support green productive investment } \\
\text { investment in the real economy is } \\
\text { promoted, non-supportive speculative } \\
\text { financial activities are restricted } \\
\text { cross-border capital controls are } \\
\text { essential to protect domestic } \\
\text { monetary policy against the threat of } \\
\text { instable flows }\end{array}$ \\
\hline
\end{tabular}

\subsubsection{Tax-Based Reformist Public Green Finance and Green Monetary Policy}

Instead of relying on subsidies as in the standard neoliberal approach, taxes on environmentally problematic activities are introduced [53]. This approach also considers the distributional implications of taxes and includes wealth and income taxes (including taxes on capital) as a central tool for raising funds for public investment in green activities. Financial resources are an important precondition for public ownership and public provision of infrastructure, e.g., in the energy sector or in the transport sector. This approach is expected to tackle environmental problems effectively [54].

Although a neoclassical perspective considers environmental taxes targeting externalities to be a legitimate instrument, it is critical of increasing taxes on wealth and higher income groups in the economy as this is expected to affect the private sector negatively. In a critical political economy perspective, it can be argued that such a reformist policy, although not directly supporting the financial sector, continues to support green private investment. Hence, it is a strategy that leads to green capitalism but does not combat environmental problems adequately [55].

The Green Deal proposed by the European Commission in December 2019 [56] mainly shares a neoliberal perspective but also contains some reformist elements. It proposes to 
reduce the risk of greenwashing by introducing standards but also argues that both public and private finance are required to transform the economy. For instance, it is intended for the European Investment Bank to increase the share of green loans from $25 \%$ to $50 \%$ of the overall portfolio. A "well-designed tax reform" (p. 17) is expected to further contribute to economic growth and increase resilience to climate changes.

In terms of monetary policy, a reformist strategy requires that central banks do not concentrate solely on financing private green activities but also directly support public green activities and investments. Instead of QE, central banks should directly finance specific green public policies, support public development banks and cooperate by using appropriate fiscal policy measures [54]. Thereby, central banks are considered powerful institutions to provide the finance needed to enable the changes necessary to transform the economy towards sustainability [57]. Heterodox economic approaches provide a rationale for these kinds of policies [58].

However, this reformist monetary policy can be criticized by a traditional neoclassical approach to money that tends to be the basis for central banking today [41]. In this perspective, central banks should abstain from financing the government as it is argued that this could lead to inflation.

\subsubsection{Command and Control Policies in Green Finance and Green Monetary Policy}

This reformist approach tries to change the context within which economic activities in the real or productive economy take place and expects that private finance responds accordingly. Hence, the starting point for introducing environmentally more friendly economic activities is not the financial sector but the rules that govern the activities in the real economy. Private sector finance follows and supports these policies. A central element of such a reformist approach includes binding regulations for the financial sector, which forbid or enforce specific financing activities [54]. The efficiency of such an approach is illustrated by successful environmental policies in the past that, for example, forbid the use of toxic substances or enforced technical standards for emissions, etc. [10].

However, in a neoclassical perspective, command and control policies are considered problematic. Against the background of neoclassical welfare economics, market-based instruments are preferred over command and control policies as they are considered to be less invasive and more efficient [19].

In monetary policy, demand and control policies represent a central element of a reformist strategy. Such measures can include lending targets, i.e., that banks are required to grant a minimum share of their loans to green activities, preferably for public activities but also for private investment. While investment in the real economy is encouraged, non-supportive speculative financial activities are restricted. Moreover, the global monetary system and the currency hierarchy [59] as well as speculative capital movements are considered problematic. For this reason, cross-border capital controls are considered essential to protect domestic monetary policy against the threat of instable flows $[8,60]$. Cross-border green financial flows are not seen as beneficial. They are expected to deepen the problems of global financial flows and monetary and financial hierarchies and dependencies [61]. In general, in this reformist perspective, strict monetary policy rules are expected to shape the financial sector in a way that contributes to green productive investment and combats undesired financial bubbles often considered to be an unavoidable side-effect of financialization [61].

UNCTAD's green new deal proposal [62] is an important example for reformist strategies and tools. It combines elements of both tax-based reformist approaches and monetary policy strategies that limit international capital flows in order to avoid these flows undermining domestic financial systems and the power of central banks, in particular in the global South. The UNCTAD report argues that financialization should be reduced. Instead, green finance with a strong emphasis on the public sector should be put to work for green capitalism. 
However, the proposal has been critiqued for promoting green capitalism and for not going far enough [63]. The standard neoclassical critique of such an approach would be again that monetary policy should focus only on price stability (and possibly financial market stability) and not care about economic growth nor intervene in the structure of the economy [27]. Continuing along these lines, regulating international capital flows is also considered problematic as it potentially intervenes in resource allocation, which is considered to be fulfilled efficiently by financial markets.

\subsection{Progressive Forms of Green Finance and Monetary Policy}

Progressive forms of green finance tend to be supported by approaches in the broader critical political economy and critical ecology that are skeptical about the possible alignment between capitalist production and environmental sustainability [14]. Progressive green finance and monetary policy can be understood against the background of de-growth perspectives and proposals of a people's green new deal [64] but also as being part of foundational thinking and strategies to contribute to a socio-ecological transformation [65]. Such an approach requires multiple and collective points of intervention, including the transformation of finance to fundamentally change the provision systems dominating under capitalism [66]. The profit motive and capitalist accumulation should cease to be the dominant drivers in the economy. These are replaced by a rational way of dealing with nature based on democratic decision making. Instead of nationalist approaches, global cooperation and solidarity are seen as key to a sustainable economy that allows decent living conditions for all globally. Against the background of different transformation strategies $[65,66]$, progressive green finance and green monetary policy are needed, while reformist approaches may only represent a first step toward a socio-ecological transformation. Progressive green finance and green monetary policy rests on two essential pillars. Firstly, similar to reformist perspectives, strict environmental rules are considered essential. However, the norms should guarantee the access of all to a fair share of environmental resources and avoid an over-use of environmental resources at a global level. Global financial transfers based on international solidarity should support this. Secondly, a transformative global monetary and financial architecture is considered a central element to facilitate financing a global socio-ecological transition (see Table 3).

Table 3. Progressive forms of green finance.

\begin{tabular}{|c|c|c|}
\hline Types & Elements and Tools of Green Finance & Monetary Policy Tools and Strategies \\
\hline $\begin{array}{l}\text { Individual rights and caps and global } \\
\text { financial transfers based on solidarity }\end{array}$ & 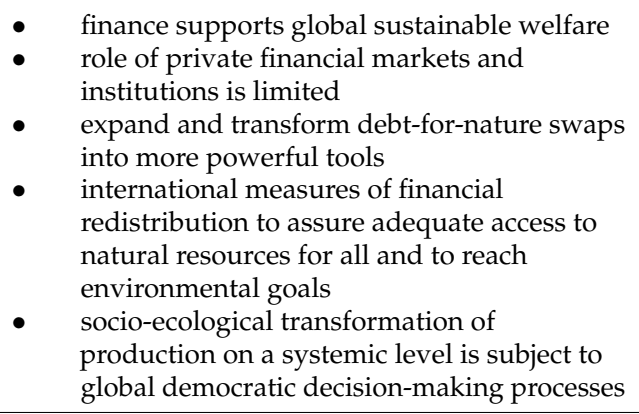 & $\begin{array}{l}\text { monetary policy supports the goal of } \\
\text { global sustainable welfare by providing } \\
\text { resources accordingly }\end{array}$ \\
\hline $\begin{array}{l}\text { Transformative global monetary and } \\
\text { financial architecture }\end{array}$ & $\begin{array}{l}\text { new global financial architecture based on } \\
\text { solidarity that avoids international debt and } \\
\text { economic dependence } \\
\text { implement global governance structures to } \\
\text { transform the economic system }\end{array}$ & $\begin{array}{l}\text { - international monetary policy } \\
\text { coordination supporting domestic } \\
\text { policies, particularly in weaker countries } \\
\text { creation of an international public digital } \\
\text { currency to anchor the financial system } \\
\text { and reduce global currency hierarchies } \\
\text { and asymmetries } \\
\text { control of private global capital flows } \\
\text { and global monetary cooperation based } \\
\text { on solidarity }\end{array}$ \\
\hline
\end{tabular}




\subsubsection{Individual Rights and Caps and Global Financial Transfers Based on Solidarity}

In such a progressive perspective, finance must support global sustainable welfare [67]. This implies that access to sufficient natural resources (goods, services) must be guaranteed for all globally. A decommodified provision of essential goods is suggested. In order to avoid a global over-use of natural resources and related negative consequences such as global warming and the loss of biodiversity, this perspective suggests limiting the over-use of natural resources by a small share of wealthy people. Moreover, this requires the reorganization of production on a systemic level, such as the implementation of a globally sustainable agriculture and other provision systems [66]. The definition of these individual rights and caps and the specific way of reorganizing global production should be subject to (global) democratic decision-making processes [10]. In order to compensate for global economic inequalities, it is necessary to implement a global system of financial transfers that guarantees that all, including the poor in the global South, have access to necessary goods. Monetary policy supports sustainable welfare in general and these global arrangements by providing resources and infrastructure accordingly.

The debt-for-nature transactions are an important example of such an approach. The first attempts of such a strategy date back to the late 1980s. They involve forgiving (part of) foreign debt obligations and allowing debtor nations to use the funds for environmental purposes [68]. More recently, debt-for-nature swaps were re-proposed within the context of the Chinese Belt and Road Initiative (BRI) [69]. Under progressive green finance, such transactions could reduce the foreign debt dependence and simultaneously contribute to reach environmental goals. While debt-for-nature transactions are an important first step, they could be expanded to transfer additional financial resources beyond a reduction of debt to the global South. Monetary policy provides a global institutional setting in order to achieve the goal of sustainable welfare by providing resources accordingly.

However, in a neoclassical perspective, such government policies are not considered desirable at all because of the expected inefficiencies. Furthermore, those who favor a reformist perspective might consider that such an approach goes too far and accuse it of being close to eco-socialism [70].

\subsubsection{Transformative Global Monetary and Financial Architecture}

Historical analysis shows that monetary policy can be deployed for purposes other than targeting inflation. Monetary policy potentially also has more instruments and power to pursue social goals than is commonly assumed [71]. In a progressive approach, the power of central banking and monetary policy should, therefore, be used. Progressive green monetary policy builds on reformist strategies but goes substantially beyond them. In particular, the international dimension of money is important.

The global financial architecture should support the goal of sustainable welfare and restrict private capital flows where needed. It should also establish international measures of redistribution to assure adequate access to natural resources for all. This means that we should abandon the mechanism of the current international financial system, which, thanks to debt relations and financial dependency, contributes to a drain of financial (and environmental) resources from the global South to the global North [61,72]. An alternative global monetary architecture should be implemented that avoids the problems of a global currency hierarchy that fosters a flow of natural resources from the global South to the global North [59,61].

International monetary policy coordination based on solidarity is, therefore, essential in a progressive strategy. Departing from the dollar-centered global currency hierarchy and the implementation of a genuine global currency that systematically favors poorer countries is considered crucial. This could be inspired by Keynes' original Bancor proposal but goes substantially beyond it. It implies that global capital flows should be systematically controlled, and the global monetary architecture should support domestic policies [60]. This would be an important precondition for the implementation of sustainable welfare. However, mechanisms of global cooperation are essential. Potentially, the recent proposals 
by the Bank for International Settlements (BIS) [73] and the People's bank of China towards a global central bank digital currency (CBDC) may lead to a revolution in the global monetary architecture. In the current form, the instruments can be classified as reformist. However, they have the potential to become progressive. The BIS and the People's Bank of China [74] have cooperated with the central banks of Hong Kong, the United Arab Emirates and Thailand and the BIS Innovation Hub in Hong Kong on a multiple CBDC (m-CBDC) project. The dominance of a single national currency at the global level could end. This would allow for a more symmetric global monetary regime. The specific features of such a global (public) digital currency would enable very specific interventions and, at a global level, would facilitate access to and control of environmental resources. Hence, democratically controlled and based on global solidarity, such a measure and a new global monetary and financial architecture could be a powerful instrument of progressive monetary policy and support progressive finance. However, it is to be seen whether $\mathrm{m}$-CBDC or a similar initiative will develop into this progressive direction.

Such far-reaching reforms of the global financial system and the global monetary regime are considered at odds with a traditional neoclassical perspective on monetary policy that focuses mainly on price stability and see a very limited role of money for the economy.

\section{Discussion}

In our contribution, we have used a deductive methodology to develop a classification of different forms of green finance and green monetary policy. We have revealed the different and often implicit underlying theoretical assumptions of various strategies in green finance and green monetary policy. It has become clear that green finance and green monetary policy should not be discussed separately but are related to each other and fit into common classifications. We have also provided examples that we consider significant in the current debates to illustrate the practical relevance of the classifications. In addition, we have provided a brief critique of the different approaches to green finance and green monetary policy approaches against the background of opposing theoretical perspectives.

The presented classification goes well beyond the dominant perspectives and discussions on green finance and green monetary policy that we have characterized as neoliberal. Moreover, we have shown that dominant neoliberal approaches are not monolithic but rather that different sub-categories, namely, laissez-faire, standard and marketmaking neoliberal green finance and green monetary policy, can be distinguished. In general, neoliberal approaches build on the assumption that market forces and a regulatory and monetary policy framework that supports private finance will effectively deal with environmental problems.

However, as outlined above, reformist and progressive approaches are skeptical of market processes and the potential conciliation between capitalism and the environment. Whilst reformist approaches to green finance and green monetary policy support a development towards green capitalism based on strict regulations, progressive forms contribute to a more fundamental transformation of the economic system in order to achieve sustainability within the context of a global socio-ecological transformation. These alternative reformist and progressive approaches to green finance and green monetary policy, although currently less visible in the political discourse, may become more relevant in the future. Moreover, against the background of heterodox economic approaches and critical political economy perspectives, these alternative measures are considered necessary to contribute to a socio-ecological transformation needed to deal effectively with global environmental problems and crises.

\section{Conclusions}

The current discussions on green finance and green monetary policy are characterized by the lack of a common framework that allows discussing systematically the different approaches and strategies to green finance on a shared ground. In this paper, we have 
provided a classification that serves as such a framework for a more systematic analysis of both green finance and green monetary policy. We have tried to keep the classification simple in order to facilitate debate about green finance and monetary policy as a whole and between fundamentally different approaches. Thereby, we have distinguished neoclassical, reformist and progressive forms of green finance and green monetary policy. This classification is based on essential different theoretical perspectives relevant for the understanding of the role of finance and money and the environment. Our classification has clearly shown that there are crucial differences and conflicting perspectives between neoliberal, reformist and progressive forms of green finance and monetary policy. Moreover, there are important differences within these three categories. This implies that the way forward in the field of green finance and green monetary policy depends very much on the adopted perspective and the underlying assumptions. Hence, instead of analyzing single measures separately, our classification allows the discussion of strategies of green finance and monetary policy in terms that are more general. Whilst the currently dominant discussions and proposals on green finance and green monetary policy can mostly be considered neoliberal, to a much lesser extent reformist and even less so progressive perspectives are present in the debates. However, this might change in the future. We believe that our classification and the analysis of the underlying assumptions, implications and the critique will help promote a broader discussion of the effectiveness of different approaches to green finance and green monetary policy in the future. Labeling specific measures not just as green or sustainable but based on our classification as neoliberal, reformist or progressive forms of green finance and monetary policy should help institutions, policy makers and the broader public to facilitate the discussions about goals and strategies regarding green finance and green monetary policy and inspire future research in this rapidly developing field.

Author Contributions: Conceptualization, E.D. and J.J.; methodology, E.D. and J.J.; investigation, E.D. and J.J.; resources, E.D. and J.J.; writing-original draft preparation, E.D. and J.J.; writingreview and editing, E.D. and J.J.; visualization, E.D. and J.J. All authors have read and agreed to the published version of the manuscript.

Funding: This research received no external funding.

Institutional Review Board Statement: Not applicable.

Informed Consent Statement: Not applicable.

Acknowledgments: We wish to thank Björn Weindorfer for the very helpful comments and for proofreading the paper. We are also very grateful to three anonymous referees for their very encouraging and helpful comments.

Conflicts of Interest: The authors declare no conflict of interest.

\section{References}

1. Berrou, R.; Dessertine, P.; Migliorelli, M. An overview of green finance. In The Rise of Green Finance in Europe. Opportunities and Challenges for Issuers, Investors and Marketplaces; Migliorelli, M., Dessertine, P., Eds.; Palgrave Macmillan: London, UK, 2019; pp. 3-29.

2. Weber, O.; ElAlfy, A. The development of green finance by sector. In the Rise of Green Finance in Europe. Opportunities and challenges for Issuers, Investors and Makretplaces; Migliorelli, M., Dessertine, P., Eds.; Palgrave Macmillan: London, UK, 2019 ; pp. 53-78.

3. Regulation (EU) No 2019/2088 of the European Parliament and of the Council of 18 June 2020 on the Establishment of a Framework to Facilitate Sustainable Investment, and Amending Regulation (EU) 2019/2088 (EU Taxonomy Climate Delegation Act). Available online: https:/ / eur-lex.europa.eu/legal-content/EN/TXT/?uri=CELEX\%3A32020R0852 (accessed on 8 July 2021).

4. EU Technical Expert Group (TEG) on Sustainable Finance. Taxonomy: Final Report of the Technical Expert Group on Sustainable Finance; TEG European Commission: Brussels, Belgium, 2020. Available online: https://knowledge4policy.ec.europa.eu/publication/ sustainable-finance-teg-final-report-eu-taxonomy_en (accessed on 29 August 2021).

5. European Commission. Communication from the Commission to the European Parliament, the Council, the European Economic and Social Committee and the Committee of the Regions: Strategy for Financing the Transition to a Sustainable Economy COM/2021/390 final. (6 July 2021) CELEX number: 52021DC0390. Available online: https:/ / eur-lex.europa.eu/legal-content/ EN-SL/TXT/?from=EN\&uri=CELEX:52021DC0390 (accessed on 15 July 2021). 
6. ECB. ECB Presents Action Plan to Include Climate Change Considerations in Its Monetary Policy Strategy. In Press Release. 8 July. Available online: https://www.ecb.europa.eu/press/pr/date/2021/html/ecb.pr210708_1 \{\}f104919225.en.html (accessed on 9 July 2021).

7. P People's Bank of China (PBC). Guidelines for Establishing the Green Financial System, Jointly Issued by the People's Bank of China, Ministry of Finance, National Development and Reform Commission, Ministry of Environmental Protection, China Banking Regulatory Commission, China Securities Regulatory Commission and the China Insurance Regulatory Commission. Available online: http:/ / www.pbc.gov.cn/english/130721/3133045/index.html (accessed on 2 May 2021).

8. Gallagher, K.P.; Kozul-Wright, R. A New Multilateralism for Shared Prosperity: Geneva Principles for a Global Green New Deal; Boston University Global Development Policy Center and UNCTAD: Boston, MA, USA; Geneva, Switzerland, 2019.

9. IMF. Global Financial Stability Report. Lower for Longer; IMF: Washington, DC, USA, 2019.

10. Jäger, J.; Schmidt, L. Global Green Finance and Sustainability: Insights for Progressive Strategies. J. Für Entwickl. 2020, 36, 4-30. [CrossRef]

11. Forstater, M.; Zhang, N. Definitions and Concepts: Background Note; UNEP Inquiry: Nairobi, Kenya, 2016.

12. Quastel, N. Ecological Political Economy: Towards a Strategic-Relational Approach. Rev. Politi-Econ. 2016, 28, 336-353. [CrossRef]

13. Castro, C.J. Sustainable development: Mainstream and critical perspectives. Organ. Environ. 2004, 17, 195-225. [CrossRef]

14. Foster, J.B. Ecology Against Capitalism. Mon. Rev. 2001, 53, 1-15. [CrossRef]

15. Smith, N. Nature as Accumulation Strategy. In Coming to Terms with Nature. Socialist Register 2007; Panitch, L., Leys, C.L., Eds.; Merlin Press: London, UK, 2006; Volume 43, pp. 16-36.

16. Liodakis, G. Mainstream and alternative theorising of the conditions and policies of sustainable development. Int. J. Sustain. Dev. 2016, 19, 147. [CrossRef]

17. Harvey, D. A Brief History of Neoliberalism; Oxford University Press: Oxford, UK, 2005. [CrossRef]

18. Bruff, I. Neoliberalism and authoritarianism. In Handbook of Neoliberalism; Routledge: London, UK, 2016; pp. 135-145. [CrossRef]

19. Anderson, D.A. Environmental Economics and Natural Resource Management; Routledge: London, UK, 2019.

20. Fink, L.A.; A Fundamental Reshaping of Finance. Larry Fink's 2020 Letter to CEOs. Available online: https://www.blackrock. com/corporate/investor-relations/2020-larry-fink-ceo-letter (accessed on 11 July 2021).

21. European Banking Authority (EBA). Action Plan on Sustainable Finance. 2019. Available online: https://eba.europa.eu/ sites / default/documents / files / document_library / /EBA\%20Action\%20plan\%20on\%20sustainable\%20finance.pdf (accessed on 11 January 2020).

22. Christophers, B. Climate Change and Financial Instability: Risk Disclosure and the Problematics of Neoliberal Governance. Ann. Am. Assoc. Geogr. 2017, 107, 1108-1127. [CrossRef]

23. Fama, E.F. Efficient Capital Markets: A Review of Theory and Empirical Work. J. Financ. 1970, 25, 383-417. [CrossRef]

24. Luo, H.A.; Balvers, R.J. Social Screens and Systematic Investor Boycott Risk. J. Financ. Quant. Anal. 2017, 52, 365-399. [CrossRef]

25. Kölbel, J.F.; Heeb, F.; Paetzold, F.; Busch, T. Can Sustainable Investing Save the World? Reviewing the Mechanisms of Investor Impact. Organ. Environ. 2020, 33, 554-574. [CrossRef]

26. Berensmann, K.; Lindenberg, N.; Green Finance: Actors, Challenges and Policy Recommendations. German Development Institute/Deutsches Institut für Entwicklungspolitik (DIE) Briefing Paper 2016, 23. Available online: https:/ / www.die-gdi.de/ briefing-paper/article/green-finance-actors-challenges-and-policy-recommendations / (accessed on 25 July 2021).

27. Saad Filho, A. Monetary Policy and Neoliberalism. In The Sage Handbook of Neoliberalism; Cahil, D., Cooper, M., Konings, M., Eds.; Sage: Thousand Oakes, CA, USA, 2018; pp. 335-346.

28. De Luigi, C.; Schuberth, H.; Feldkircher, M.; Poyntner, P.; Effects of the ECB's unconventional monetary policy on real and financial wealth. WU Department of Economics Working Paper Series 2019, (286). Available online: https:/ / epub.wu.ac.at/7040/ (accessed on 28 July 2021).

29. Matikainen, S.; Campiglio, E.; Zenghelis, D. The Climate Impact of Quantitative Easing. Policy Paper, Grantham Research Institute on Climate Change and the Environment, London School of Economics and Political Science 2017, 36. Available online: https:/ / www.lse.ac.uk/granthaminstitute/publication/the-climate-impact-of-quantitative-easing/ (accessed on 28 July 2021).

30. Harris, J.M.; Roach, B. Environmental and Natural Resource Economics: A Contemporary Approach; Routledge: London, UK, 2017.

31. Dang, D. Can environmental subsidies promote the green investment of enterprises? Mod. Econ. 2020, 11, 109. [CrossRef]

32. Eichner, T.; Runkel, M. Subsidizing renewable energy under capital mobility. J. Public Econ. 2014, 117, 50-59. [CrossRef]

33. Dafermos, Y.; Gabor, D.; Michell, J. The Wall Street Consensus in pandemic times: What does it mean for climate-aligned development? Can. J. Dev. Stud./Rev. Can. D'études Du Développement 2021, 42, 238-251.

34. Taghizadeh-Hesary, F.; Yoshino, N. The way to induce private participation in green finance and investment. Finance Res. Lett. 2019, 31, 98-103. [CrossRef]

35. Claar, S. Green Finance and Transnational Capitalist Classes-Tracing Vested Capital Interests in Renewalbe Energy Investments in South Africa. J. Für Entwickl. 2020, 36, 110-128. [CrossRef]

36. Campiglio, E.; Dafermos, Y.; Monnin, P.; Ryan-Collins, J.; Schotten, G.; Tanaka, M. Climate change challenges for central banks and financial regulators. Nat. Clim. Chang. 2018, 8, 462-468. [CrossRef]

37. Papoutsi, M.; Piazzesi, M.; Schneider, M. How Unconventional is Green Monetary Policy; Working Paper: Stanford University. Available online: https://web.stanford.edu/ \{\}piazzesi/How_unconventional_is_green_monetary_policy.pdf (accessed on 7 May 2021). 
38. Ferrari, A.; Nispi Landi, V. Whatever it takes to save the planet? Central banks and unconventional green policy. Central Banks and Unconventional Green Policy (15 February 2021). Bank of Italy Temi di Discussione (Working Paper) No $2021,1320$. Available online: https:/ /www.bancaditalia.it/pubblicazioni/temi-discussione/2021/2021-1320/index.html?com.dotmarketing. htmlpage.language $=1$ (accessed on 29 July 2021).

39. Van Gansbeke, F. Why Central Bank Digital Currencies (CBDC) Now And What They Could Mean For Climate Change? Forbes. Available online: https:/ /www.forbes.com/sites/frankvangansbeke/2021/06/27/why-central-bank-digital-currencies-cbdcnow-and-what-could-they-mean-for-climate-change-12/?sh=3d1208f124a8 (accessed on 27 June 2021).

40. Hansen, L.P. Central Banking Challenges Posed by Uncertain Climate Change and Natural Disasters. University of Chicago, Becker Friedman Institute for Economics Working Paper. 2021. Available online: https://doi.org/10.1016/j.jmoneco.2021.09.010 (accessed on 19 September 2021). [CrossRef]

41. Schoenmaker, D. Greening monetary policy. Clim. Policy 2021, 21, 581-592. [CrossRef]

42. Braun, B. Central banking and the infrastructural power of finance: The case of ECB support for repo and securitization markets. Socio-Econ. Rev. 2018, 18, 395-418. [CrossRef]

43. Klooster, J.V.; Fontan, C. The Myth of Market Neutrality: A Comparative Study of the European Central Bank's and the Swiss National Bank's Corporate Security Purchases. New Politi-Econ. 2019, 25, 865-879. [CrossRef]

44. Nedopil, C.; Dordi, T.; Weber, O. The Nature of Global Green Finance Standards-Evolution, Differences, and Three Models. Sustainability 2021, 13, 3723. [CrossRef]

45. European Investment Bank and Green Finance Committee of China Society for Finance and Banking (EIB and GFC) The Need for a Common Language in Green Finance; European Investment Ban. Available online: https://www.eib.org/attachments/press / white-paper-green-finance-common-language-eib-and-green-finance-committee.pdf (accessed on 11 October 2018).

46. Bracking, S. Financializaion and the Environmental Frontier. In The Routledge International Handbook of Financialization; Mader, P., Mertens, D., van der Zwan, N., Eds.; Routledge: London, UK, 2020; pp. 213-223.

47. Brand, U.; Wissen, M. The Limits to Capitalist Nature. Theorizing and Overcoming the Imperial Mode of Living; Rowman \& Littlefield: London, UK, 2018.

48. D'Orazio, P.; Popoyan, L. Fostering green investments and tackling climate-related financial risks: Which role for macroprudential policies? Ecol. Econ. 2019, 160, 25-37. [CrossRef]

49. Network of Central Banks and Supervisors for Greening the Financial System (NGFS). Guide for Supervisors: Integrating Climate-Related and Environmental Risks into Prudential Supervision. 2020. Available online: https://www.ngfs.net/sites/ default/files/medias/documents/ngfs_guide_for_supervisors.pdf (accessed on 2 June 2020).

50. Feridun, M.; Güngör, H. Climate-Related Prudential Risks in the Banking Sector: A Review of the Emerging Regulatory and Supervisory Practices. Sustainability 2020, 12, 5325. [CrossRef]

51. Gabor, D. Greening the European Financial System. Three Ideas for a Progressive Sustainable Finance Agenda. The Foundation for European Progressive Studies (FEPS) Policy Brief June 2020. Available online: https: / /www.feps-europe.eu/attachments / publications / feps\%20paper\%20three\%20ideas\%20gabor.pdf (accessed on 7 July 2020).

52. Douai, A.; Mearman, A.; Negru, I. Prospects for a heterodox economics of the environment and sustainability. Camb. J. Econ. 2012, 36, 1019-1032. [CrossRef]

53. Semmler, W.; Braga, J.P.; Lichtenberger, A.; Toure, M.; Hayde, E. Fiscal Policies for a Low-Carbon Economy; World Bank: Washington, DC, USA, 2021. [CrossRef]

54. Reyes, O. Change Finance, Not the Climate; Trans National Institue/Institute for Policy Studies: Amsterdam, The Netherlands; Washington, DC, USA, 2020.

55. Brand, U.; Daiber, B. Green Economy and Green Capitalism: Some Theoretical Considerations. J. Für Entwickl. 2012, 28, 118-137. [CrossRef]

56. European Commission. European Green Deal; European Commission: Brussels, Belgium, 2019.

57. Galvin, R. Yes, there is enough money to decarbonize the economies of high-income countries justly and sustainably. Energy Res. Soc. Sci. 2020, 70, 101739. [CrossRef] [PubMed]

58. Lagoarde-Segot, T. Financing the Sustainable Development Goals. Sustainability 2020, 12, 2275. [CrossRef]

59. Svartzman, R.; Althouse, J. Greening the international monetary system? Not without addressing the political ecology of global imbalances. Rev. Int. Politi-Econ. 2020, 1-26. Available online: https://www.tandfonline.com/doi/abs/10.1080/09692290.2020.18 54326 (accessed on 27 August 2021). [CrossRef]

60. Fieldman, G. Finance Unchained: The Political Economy of Unsustainability. Sustainability 2020, 12, 2545. [CrossRef]

61. Jäger, J.; Schmidt, L. The Global Political Economy of Green Finance: A Regulationist Perspective. J. Für Entwickl. 2020, 36, 31-50. [CrossRef]

62. UNCTAD Trade and Development Report 2019. Financing a Global Green New Deal; United Nations Conference on Trade and Development. Available online: https://unctad.org/en/PublicationsLibrary/tdr2019_en.pdf (accessed on 11 January 2020).

63. Perry, K.K. Financing a Global Green New Deal: Greening Capitalism or Taming Financialization for a New 'Civilizing'Multilateralism? Dev. Chang. 2021, 52, 1022-1044. [CrossRef]

64. Ajl, M. A People's Green New Deal: Obstacles and Prospects. Agrar. South J. Politi-Econ. 2021, 10, 371-390. [CrossRef]

65. Bärnthaler, R.; Novy, A.; Plank, L. The Foundational Economy as a Cornerstone for a Social-Ecological Transformation. Sustainability 2021, 13, 10460. [CrossRef] 
66. Schaffartzik, A.; Pichler, M.; Pineault, E.; Wiedenhofer, D.; Gross, R.; Haberl, H. The transformation of provisioning systems from an integrated perspective of social metabolism and political economy: A conceptual framework. Sustain. Sci. 2021, 16, 1405-1421. [CrossRef]

67. Koch, M.; Buch-Hansen, H. The IPE of degrowth and sustainable welfare. In The Routledge Handbook to Global Political Economy; Vivares, E., Ed.; Routldge: London, UK, 2020; pp. 375-390.

68. Sheikh, P.A. In Debt-for-Nature Initiatives and the Tropical Forest Conservation Act: Status and Implementation, 2004; Congressional Research Service; The Library of Congress: Washington, DC, USA, 2004.

69. Yue, M.; Wang Nedopil, C. Debt-For-Nature Swaps: A Triple-Win Solution for Debt Sustainability and Biodiversity Finance in the Belt and Road Initiative (BRI)? IIGF Green BRI Cente: Beijing, China, 2021.

70. Somerville, P. Revisiting Connections between Capital and Nature II: The Case of Climate Change. Capital. Nat. Soc. 2020, 32, 40-55. [CrossRef]

71. Braun, B.; Downey, L. Against Amnesia: Re-Imagining Central Banking; Council on Economic Policies: 2020. Available online: https://www.cepweb.org/against-amnesia-re-imagining-central-banking/ (accessed on 27 July 2021).

72. Soederberg, S. Debtfare States and the Poverty Industry: Money, Discipline and the Surplus Population; Routledge: London, UK, 2014.

73. BIS. CBDCs: An Opportunity for the Monetary System; BIS Annual Report, Chapter 3: Bank for International Settlements; BIS: Basel, Switzerland, 2021.

74. People's Bank of China (PBC). Progress of Research \& Development of E-CNY in China, Working Group on E-CNY Research and Development of the People's Bank of China. July 2021. Available online: http:/ / www.pbc.gov.cn/en/3688110/3688172/415744 3/4293696/2021071614584691871.pdf (accessed on 2 August 2021). 